\title{
Determinants of Capital Integration among Strategic Alliance Members in the Retail Sector: Evidence from Central and Southeast European Countries
}

\section{Nikola Butigan}

Managing Director, Pemo Ltd., Dubrovnik, Croatia

nikola.butigan@pemo.hr

\section{Đuro Benić}

University of Dubrovnik, Department of Economics and Business Economics, Dubrovnik, Croatia

dbenic@unidu.hr

\author{
CroEconsur \\ Vol. 18 \\ No. 2 \\ December 2016 \\ pp. $77-112$
}

Received: October 7, 2016

Accepted: November 16, 2016

Research Article

doi:10.15179/ces.18.2.3

\section{Abstract}

Survival of firms requires continuous search for new and a restructuring of the existing competitive advantages. These can come either from firms' internal factors or from cooperation with the environment. Cooperation among firms commonly takes place through the formation of strategic alliances. However, such form of cooperation presents only one stage in the integration of business entities. In the long run, strategic alliances can cease to exist or transform into a higher form of association based on capital integration. The objective of this paper is to explore the determinants of capital integration among strategic alliance member firms in retail sectors of several Central and Southeast European countries. Overall, the obtained findings suggest that business entities engage in integration with the aim of reaching hidden knowledge and skills, accessing distribution and supply channels, and developing new products and services. Integration is also 
driven with the aim of risk diversification and possible better market positioning, achieving the economies of scale, and improving organization and marketing. The opportunistic behavior of partners and limited managerial control represent its strongest barriers.

Keywords: strategic alliance, capital integration, retail, CEEC, SEEC

JEL classification: D22, D74

\section{Introduction}

The survival of firms in modern times frequently requires various forms of cooperation. For many firms these processes happen through the formation of strategic alliances. However, such form of cooperation presents only one stage in the integration of business entities. In the long run, strategic alliances can cease to exist or transform into a higher form of association based on capital integration. Institutionalization of strategic alliances through capital integration enables numerous benefits in terms of both revenues and costs. On the one hand, greater negotiating power and financial consolidation lead to cost efficiency. On the other hand, capital integration enables market differentiation thus paving the way for better competitiveness, higher market share and growth of revenues. Finally, capital integration improves the ability of a business entity to resist a hostile takeover.

Transformation of strategic alliance into institutionalized form of cooperation comes with numerous challenges for the involved business entities. These can take the form of a restructuring, an introduction of new organizational practices and may require willingness to make compromise in decision-making. The latter is of particular challenge for firms where management and ownership are not separated. Capital integration also paves the way for changes in management as some overlapping positions become redundant. In addition to these factors, 
the propensity of some strategic alliance members towards capital integration is determined by a number of other factors. Differences in performance can act as an obstacle to further development and strengthening of strategic alliances and thus reduce the readiness for capital integration. In a parallel development, the misalignment between subjective valuation of owners and an independent assessment of the value of their firms can yield a similar effect. The decision on capital integration is also related to expectations about the effects of planned synergy and the attitude of owners and managers towards the loss of independence and control.

Keeping the above said in mind, the objective of this paper is to explore which factors and forces determine the propensity of strategic alliance members towards capital integration. To this end, the research posits several questions. What is the impact of individual performance of strategic alliance members on propensity towards capital integration? Does value assessment determine the decision on capital integration? What is the impact of expected future profits on capital integration? To what extent do loss of independence and control determine the decision on capital integration?

The answer these questions, a survey was conducted among the owners and managers of more than 700 business entities in retail sectors of several Central and Southeast European countries (CEECs and SEECs) (Croatia, Slovenia, the Czech Republic, Slovakia, Hungary, Poland, Estonia, and Bosnia and Herzegovina). The analysis was undertaken with the means of a multinomial logit econometric technique which enables the assessment of the impact of individual determinants on the differences in propensity of strategic alliance member firms towards capital integration. The rest of the paper is structured as follows: Section two provides a theoretical framework of research, while a review of the existing literature is undertaken in the third Section. The dataset is presented in Section four. The model and methodology of investigation is discussed in Section five, followed by a presentation of findings in Section six. Section seven provides the concluding remarks. 


\section{Theoretical Framework}

Survival and expansion of business entities requires continuous upgrading of the existing and the development of new competitive advantages. This process can take place either through one's own resources or through cooperation with other business entities. One of the most common forms of association between business entities are strategic alliances and joint ventures. The weakness of such organizational forms reflects itself primarily in a limited period of duration, narrowly defined as a purpose of cooperation and the inability of a response to complex business challenges in a high-risk environment (Yin and Shanley, 2008). An alternative form of cooperation is the institutional association or capital integration where two or more business entities merge their resources through joint ownership.

Over the past decades, several economic schools of thought have attempted to explain the motives of business entities for resource integration instead of market interactions. Within this literature, economies of scale, knowledge and technology transfer, as well as the ease of access to suppliers and distributors are often cited as reasons for preference of capital integration over weaker forms of association such as strategic alliances. To this end, one can distinguish views of resource dependence theory, transaction costs economics, industrial organization, and institutional economics.

According to resource dependence theory, the primary reason behind the integration of business entities is the greater negotiating power over suppliers. Within this line of thinking, the market power of some business entities over others lies in the role of the resource supplier. From the buyers' perspective, such relationship presents a continuous source of uncertainty about the terms of transactions, which put them in an unfavorable position. For all the mentioned, upstream positioned business entities (buyers) will tend to reduce their dependence on external resources (Pfeffer and Salancik, 2003; Hillman, Withers and Collins, 2009; Davis and Cobb, 2010). 
The achievement of a previously defined objective is possible in two ways. On the one hand, one's own efforts can be invested in search for alternative resources to reduce the dependency on a particular supplier. On the other hand, resource dependence theory notes that the negotiating power of buyers increases whereas that of suppliers is being reduced with an increase in the size of buyers. Business entities will, therefore, invest their efforts in the achievement of higher growth rates. However, in the context of this paper, the most important contribution of resource dependence theory is that it points towards association among business entities as a potential channel for the diminishment of suppliers' negotiating powers whether through strategic alliances or institutional association. From there it follows that the vertically integrated association of business entities primarily takes place with the aim of reducing and eliminating opportunistic behavior of vertically related business entities.

Association can also emerge among horizontally related business entities. Here, firms are confronted with a trade-off. Individual efforts to find alternative resources enable a wide autonomy in decision-making. At the opposite end of the spectrum, institutional binding with other business entities entails a loss of freedom over decision-making. Resource dependence theory notes that horizontal association entails a loss of control and management while leading to lower effects of reduced interdependencies than those that could be achieved through diversification. The message, which can be discerned from the literature, is that the loss of power and decision rights destimulates owners and managers towards institutional binding. Hence, business entities will favor such behavior only when considerable control over a potential partner is required.

Transaction costs economics puts the choice of business entities between strategic alliance and capital integration in the context of uncertainty over market transactions (Coase, 1937; Williamson, 1985). Capital integration in this context is an attempt of firms to prevent opportunistic behavior of those business entities on which they depend in the supply of resources or other goods and services. Under market imperfections, frequent transactions of specific resources 
expose business entities to the risk of changing business conditions or even to the hold up in the production, supply or distribution. According to transaction costs economics, the exposure to opportunistic behavior can be achieved through different forms of cooperation between business entities ranging from short- and long-term cooperation agreements to capital integration. The tendency towards institutional association will increase with the rise in frequency of transactions, resource specificity and uncertainty.

Industrial economics exhibits a tendency towards capital integration with industry characteristics of business entities. The starting point within this approach is the structure-conduct-performance paradigm (Bain, 1968; Hendrikse, 2003). Capital integration is seen as a path for collusion on highly concentrated markets. Yin and Shanley (2008) note that the tendency towards the institutionalization of cooperation between business entities will be higher for those subjects with a greater choice of business partners. Finally, the nature of rivalry within individual industries will determine the propensity towards and the extent of association. Business entities in industries that require flexibility will favor individual activities or weaker forms of association.

The choice between strategic alliances and capital integration can also be explained within institutional economics (North, 1990). The starting point here is the view of institutions as mechanisms which reduce the risk of opportunistic behavior, simplify the decision-making process and define the boundaries of acceptable actions. From there it follows that capital integration will be favored as a mechanism for the prevention of opportunistic behavior in a weaker institutional environment. Such reasoning is consistent with the transaction costs economics' view that integration of business entities emerges in the presence of market imperfections such as the low level of development of institutional framework.

The discussion above points to three main views concerning the propensity of business entities towards capital integration. On the one hand, the propensity towards capital integration is driven by the desire to minimize the possibility of 
opportunistic behavior of business partners. On the other hand, possibilities of collusion and expansion on concentrated markets, and thus better performance, act as an additional motive for integration. Finally, capital integration emerges from the efforts of business entities to improve their performance in an underdeveloped institutional environment.

\section{Literature Review}

Determinants of propensity towards capital integration among firms have been investigated by a number of authors. Majority of this research is focused on developed countries while developing economies have been the subject of investigation to a lesser extent. The starting point for the majority of studies is the choice of business entities in undertaking of activities between market mechanisms, weaker forms of association such as strategic alliances and highly integrated associations such as joint ventures or capital integration through mergers or acquisitions. When it comes to the propensity towards capital integration, evidence points to the persistence of certain features in the behavior of business entities.

Evidence from some studies support views expressed by the transaction costs economics and resource dependence theory regarding the positive relationship between resource specificity and the risk of opportunistic behavior on the one hand, and the propensity towards capital integration, on the other hand (Dyer, Kale and Singh, 2003; Villalonga and McGahan, 2005; Geyskens, Steenkamp and Kumar, 2006). The above mentioned suggests that business entities strive to reduce the risk from negative externalities of market imperfections, such as a hold up or renegotiation of transactions. The transition from lower toward higher forms of association (e.g., from strategic alliances towards institutional integration) also depends on the aims of business entities. Strategic alliances seem to be a favorable form of association for business entities aiming at a smaller number of objectives (Wegberg, 1995). However, being based on contracts, they 
fall short to optimal when association is drawn with more complex situations. In such conditions, capital integration is a more acceptable option.

The propensity towards capital integration also depends on industry and market characteristics (Hakansson and Snehota, 1995; Trapido, 2007; Haworth, Owen and Yawson, 2012). Higher frequency of business interactions broadens knowledge on the behavior of rivals and potential partners thus reducing the risk of opportunistic behavior. Furthermore, the number of business entities within a given industry determines the number of potential partners and relates the survival of firms with the need for association. Among industry characteristics, existing studies also point to technological intensity and a form of competition. The propensity towards capital integration seems to be higher in high technologyintensive sectors characterized by high resource specificity and larger financial challenges of investment in research and development. However, the constraints of institutional integration lead to an adverse attitude towards firms in sectors characterized by dynamic market competition (Hoffman and Schaper-Rinkel, 2001). Finally, Haworth, Owen and Yawson (2012) note that business entities, which are threatened by their rivals and whose growth is constrained with the size of their own resources, will exhibit greater tendency towards capital integration.

The choice between different forms of association also depends on the attitudes of managers and owners. On the one hand, business entities engage in associations seeking expansion and better performance. Madhok and Tallman (1998) and $\mathrm{Li}$ and Prabhala (2007) suggest that the possibility for profit growth, market share and shareholders value is connected in favor of institutional association. Findings of other authors emphasize the importance of managerial incentives and attitudes. The possibility of influence on strategic decisions and activities enables trust building and prevents the opportunistic behavior of partners. The research within organizational learning theory (Cyert and March, 1963) suggests that joint decision making precipitates knowledge transfer and absorption among partners. Findings of a few authors suggest that the tendency towards capital integration is lower when eventual association implies a loss of decision-making 
power for managers and owners of business entities (Saxton, 1997; Haworth, Owen and Yawson, 2012).

The success and feasibility of capital integration is also determined by the degree of similarity between organizational structures of business entities (Hakansson and Snehota, 1995; Trapido, 2007). The value added creation potential within a united business entity is larger for organizations with similar structures. On the one hand, institutional association eliminates redundant activities and leads to economies of scale, while on the other hand, a high degree of complementarity favors knowledge and technology transfer between partners and enables development of new competitive advantages through the pooling of individual partner knowledge (Wang and Zajac, 2007).

Existing studies attach particular importance to the dependency of business entities on external resources and efforts to minimize the opportunistic behavior of partners. To this end, the relevance of previous cooperation through weaker forms of partnership such as strategic alliances is emphasized (Saxton, 1997; Anand and Khana, 2000; Villalonga and McGahan, 2005; Kayo et al., 2010; Boone and Ivanov, 2012; Chang and Tsai, 2013; Yu and He, 2014; Fang et al., 2015; Fich, Nguyen and Officer, 2015). The history of cooperation favors reputation building, helps to develop mutual trust and reduces uncertainty regarding the potential actions of a partner. Findings within this line of research point to differences between synergy benefits of associations among domestic business entities and international partnerships. Due to cultural and sociological differences, transaction costs tend to be higher in international partnerships, thus reducing the positive effects of synergy.

Findings on the transformation of strategic alliances into capital integration point to differences between horizontal partnerships of business entities within the same industry and vertical associations with suppliers and distributors. Yu and He (2014), using the 1986-2010 data, suggest that horizontal partnerships aim at cost efficiency through economies of scale. Vertical associations on the other 
hand, enable the institutionalization of specific resources and ease the knowledge transfer between upstream and downstream firms. From there it follows that the tendency towards capital integration will be higher among vertically related business entities. Besides previous cooperation through strategic alliances, the propensity towards a particular form of association is determined by general experience in pursuit of a certain strategy (Barkema and Schijven, 2008; Kayo et al., 2010). The complex nature of capital integration makes the related learning process extremely demanding. This primarily refers to the negotiating process, mutual value assessment, finance, integration etc. Therefore, business entities tend to rely on the existing knowledge and learned routines consistent with the propositions of evolutionary theory (Nelson and Winter, 1982).

Other investigated determinants of propensity towards capital integration include the size of business entities, the diversification of their products and services and ownership (Villalonga and McGahan, 2005; Haworth, Owen and Yawson, 2012; Yu and He, 2014). Findings of a positive relationship between firm size and a tendency towards association with other business entities signals the existence of relevant financial and nonfinancial resources in large firms that can be used for integration with other counterparts. Existing findings also suggest the heterogeneity of business entities towards capital integration with respect to ownership. Finally, the tendency towards capital integration is larger among those business entities whose activities are diversified across a number of sectors than among their counterparts focused on a single sector.

The transition from strategic alliances towards capital integration has also been investigated in the context of the retail sector. Chatterjee (2004) notes that the propensity towards capital integration exhibits an upward tendency with an increase in personal satisfaction concerning the functioning of strategic alliance in general and partner behavior in particular. Furthermore, business entities within this sector enter such arrangements with the aim to reduce dependency on market resources. Barros, Brito and Lucena (2006) conclude on a sample of firms from the Portuguese retail sector that capital integration enables price 
control of the involved business entities. Clarke-Hill, Robinson and Bailey (1998) also associate capital integration with greater competitive advantages, better product planning strategies and stronger learning effects when compared to strategic alliances.

Even though the relationship between the variety of factors and the propensity towards capital integration has been investigated in the existing literature, to the best of our knowledge, there has been no attempt to research propensity towards capital integration among strategic alliance member firms in general and in the retail sector in particular. Furthermore, studies on capital integration processes in Central and Southeast European countries (CEECs and SEECs) are rare and nonexistent in the context of the retail sector. The gap is particularly pronounced in case of countries such as Croatia or Bosnia and Herzegovina where these issues have not been investigated at all. The rest of paper aims to fill this gap.

\section{The Data and the Questionnaire}

Keeping in mind the aforementioned, the aim of this chapter is to explore which factors and forces determine the propensity of strategic alliance member firms from retail sector towards capital integration. Since the existing databases do not provide such information and it is not possible to establish the total number of retail firms, which are members of the strategic alliance, a survey was undertaken, for the purpose of this paper, among business entities members of strategic alliances in the retail sectors of eight Central and Southeast European countries (Croatia, Slovenia, Bosnia and Herzegovina, Hungary, the Czech Republic, Slovakia, Poland, and Estonia). The primary source of data was the Amadeus database, the best publicly available source of data on business entities in Europe. It is from there that the names, addresses and other relevant information on firms in the retail sector of all analyzed countries were taken from.

Particularly valuable information was the indicator of participation in strategic alliance. However, even though Amadeus is commonly labeled as the best pan- 
European firm-level database, it is not immune to weaknesses. The information on some or all variables for a certain proportion of firms is missing and the information on membership in the strategic alliance is not an exception from this occurrence. In order to maximize the sample, the questionnaire was emailed to all business entities from the retail sector contained in the database in September 2014. This way, out of 3753 retail firms in the database, 736 filled out the questionnaire which constitutes about 19 percent of all respondents. In a sizeable number of cases, participation in the survey was denied due to a corporate prohibition of such activity. Table 1 provides an overview of a number of distributed questionnaires and the response rate.

Table 1: Geographic Distribution and the Number of Respondents

\begin{tabular}{|c|c|c|c|}
\hline Country & $\begin{array}{l}\text { Number of sent } \\
\text { questionnaires }\end{array}$ & Number of responses & Response rate, in \% \\
\hline Croatia & 1642 & 314 & 19 \\
\hline $\begin{array}{l}\text { Bosnia and } \\
\text { Herzegovina }\end{array}$ & 207 & 23 & 11 \\
\hline Slovenia & 287 & 16 & 6 \\
\hline Slovakia & 911 & 147 & 16 \\
\hline The Czech Republic & 156 & 45 & 29 \\
\hline Hungary & 142 & 60 & 42 \\
\hline Poland & 286 & 87 & 30 \\
\hline Estonia & 122 & 44 & 20 \\
\hline Total & 3853 & 736 & 19 \\
\hline
\end{tabular}

Source: Authors' calculations.

The questionnaire consists of three sets of questions: general characteristics of a business entity, questions about participation in strategic alliance and questions on attitudes towards positive and negative effects of potential capital integration. In the following segments, we outline the main features for each group of questions. 


\subsection{General Characteristics of a Business Entity}

The first group of questions encompasses the size of business entities measured with the average number of employees in three years prior to the survey, the ownership_-defined by the respondents as predominantly domestic- or foreignowned, and the year of foundation. In addition to these characteristics, the subjects were asked to assess one's own profitability and the growth of revenues relative to those of their rivals over a three-year period prior to the survey (above average, average, and below average), and to provide information on the profitability and revenue growth over the mentioned period.

\subsection{Participation in Strategic Alliance}

The second part of the questionnaire provides information on the participation of business entities in strategic alliances. Respondents were asked to provide information on the number of firms within the strategic alliance with answers defined as: up to two members, between three and five, and more than five members. Another question asked for the percentage of ownership over strategic alliance by the respondent firm (0-25 percent; $25-50$ percent; 50-75 percent; and 75-100 percent). Respondents were also asked to assess their autonomy within the strategic alliance with respect to the management of daily activities, human resources management, marketing and distribution, cost, price and product management, and capital investment. The answers were defined on a four point scale ranging from no autonomy over limited and high degree of autonomy to complete autonomy. Finally, firms were asked to estimate the percentage of their management actively involved in the management of strategic alliance. The descriptive analysis revealed that in over 85 percent of cases surveyed, business entities participated in alliances with more than five members and controlled less than 25 percent of ownership. In about half of the surveyed firms, more than two thirds of managers were actively involved in the management of the strategic alliance. 
Respondents were also asked to assess whether participation in the strategic alliance resulted in the introduction of organizational and marketing innovations. With respect to the former, the question aimed at changes in the supply chain and knowledge management, quality, environment protection, new methods for the organization of relationships with an external environment and for the organization of work activities and the decision-making process, such as team work, decentralization, merger and division of departments, education and training. The second question focused on design changes, packaging and presentation of products, new channels for presentation and sales of products and new pricing methods. For both questions, the dichotomous (yes/no) answer was permitted. Over 80 percent of firms attributed the introduction of organizational and marketing innovations as those described above to participation in strategic alliance.

Two questions in this part of the survey aimed at the effect strategic alliance exerts over the requirements set out for internationally recognized standards in quality management and environment protection. Respondents were asked whether internationally recognized certificates of quality (e.g., ISO) and environment protection (e.g., EMAS) were introduced due to participation in the strategic alliance. About one fifth of respondents provided an affirmative answer to the question.

In another set of questions, respondents were asked to assess the role of previous cooperation with the members of strategic alliance for several activities including trust building, knowledge and skill transfer, and decision-making within the alliance. Here, the respondents were required to choose from five answers (irrelevant, relatively unimportant, relatively important, very important, and absence of previous cooperation with strategic alliance members). Over 80 percent of respondents considered previous cooperation important for trust building, knowledge and technology transfer. Furthermore, more than half of the respondents find previous cooperation important for the decision-making process within the alliance. 


\subsection{Attitudes toward Capital Integration}

The final part of the questionnaire was devoted to the attitudes of business entities toward the possibility of capital integration. Here, the respondents were asked to assess the prospects of capital integration among strategic alliance members defined as unlikely, likely, and very likely. More than half of the respondents did not find the transformation of strategic alliance toward capital integration likely. About 30 percent of those surveyed consider capital integration likely, while such a scenario is very likely for about one fifth of the respondents.

Three more questions were asked concerning respondents' expectations on the effects of potential capital integration on several aspects of firm performance. In the first two questions, responses were constructed as consisting of four options (irrelevant, relatively unimportant, relatively important, and very important). The first question focused on the expectations of benefits from potential capital integration defined as higher market share, product range, sales revenues, return on assets, $\mathrm{P} / \mathrm{E}$ ratio, customer satisfaction, expansion to new markets, organizational improvements, and the expansion of capacities. Among these, the majority of respondents identified higher market share, greater range of products, and the expansion of capacities as either relatively or very important. In the second question, the emphasis was on the expectations concerning the potential downsides of capital integration defined as higher costs of coordination and business, loss of managerial control, and the opportunistic behavior of partners. Loss of control over decision-making, the opportunistic behavior of partners and higher costs of coordination are considered as relatively or very important barriers to capital integration for the majority of respondents. Finally, the third question aimed to assess the importance of expectations about shortand long-run profits for the prospects of capital integration. 


\section{The Model and Methodology}

On the basis of the previously mentioned data, a model was developed for the analysis of the relationship between the propensity of strategic alliance member firms towards capital integration and the set of variables-including general characteristics of business entities, strategic alliance characteristics and attitudes of business entities towards the effects of potential capital integration. In general, the form model can be formulated as follows:

\section{Propensity $_{i}=f$ (Business entity characteristics $;$; Strategic alliance characteristics $_{i} ;$ Effects of integration $_{i}$ )}

The dependent variable in equation 1 is defined on the basis of the responses to the question concerning the prospects of capital integration among the members of strategic alliance. As explained previously, three outcomes are defined as attitudes of respondents toward the prospects of capital integration: unlikely, likely, and very likely.

Through various forms of cooperation, strategic alliance members jointly participate on the market. A stronger form of cooperation, such as capital integration, leaves open the question of individual firms' contribution to the success of strategic alliance. Differences in performance can act as an obstacle to further development and the strengthening of the alliance. To explore the relationship between individual performance of member firms and their propensity towards capital integration, the model includes a variable defined as the ratio between the average Return on assets (ROA) of a firm over a three-year period prior to the survey and the average return on assets of its industry. These data were taken from the Amadeus database. A negative effect of this variable labeled Performance on propensity towards capital integration is expected.

Integration of business entities requires the measurement of growth and a combination of values of two or more subjects. On the one hand, client base and market size grow while on the other hand, capital integration leads to 
cost reduction and synergy effects. One of the basic preconditions for capital integration is an independent, separate assessment of value for each subject and an estimation of the desired synergy effects. For this reason, the variable Valuedefined as a ratio between the subjective and objective value assessment-is included. This variable is constructed from two variables as it is explained below.

In section 4.1 it was mentioned that one of the survey questions required respondents to assess their own profitability relative to those of their rivals over a three-year period prior to the survey as: below average, average or above average. These responses were used in the construction of the Value as a subjective assessment of a firm value. Section 4.1 also explained that the respondents were asked to provide actual figures on their performance (profitability) in three years prior to the survey. In the construction of an objective value assessment, these data were matched with the data from the Amadeus database. Specifically, the Amadeus database was used to obtain information on the average profitability of firms in retail sectors of analyzed countries over a three-year period prior to the survey. From there, actual average performance of the analyzed firms over a three-year period prior to the survey was divided with the average performance figures for retail sector firms in each given country. This, in turn, enabled us to divide the surveyed firms into three categories on the basis of their objective value assessment as: the top 40 percent performers (above average), the bottom 40 percent performers (below average), and the medium 20 percent performers (average). Hence, objective value assessment in the three years prior to the survey was finally defined as below average, average, and above average analogous to the subjective performance assessment.

The expression of subjective and objective performance in the same categories (below average, average, and above average) enabled us to establish a relationship between the subjective and objective value assessment in a three-year period prior to the survey and from there to divide firms into three groups. The first group includes those entities whose subjective assessment is lower than the objective assessment. Business entities whose subjective and objective assessments match 
each other are in the second group. Finally, those firms whose subjective assessment exceeds the objective one fall into the third group.

It is expected that the subjects whose own (subjective) assessment of value underscores the objective assessment are more inclined towards capital integration than those where two assessments match each other or those where the subjective assessment exceeds the objective one. Hence, from there it is possible to finally construct the variable Value which takes 1 if the subjective assessment is lower than the objective one (firms where the subjective assessment is below average but objective are average or above average, and firms where the subjective assessment is average, but objective, are above average) and 0 elsewhere (if the subjective and objective value assessments match each other or if the subjective assessment is higher than the objective one). A positive sign is expected on this variable.

In firms where ownership and management are not separated the decision on capital integration will be related to the trade-off between the loss of independence and management control on the one hand and the expected synergy effects on the other hand. To explore the importance of these factors, the model includes a categorical variable Control which takes the value of 1 if the respondents consider the loss of management rights to be an important determinant of capital integration. The model also includes several variables which control potential positive synergy effects of capital integration. Two categorical variables are included for business entities which consider the prospects of short-run and longrun profits (Lrprof and Srprof) important for the decision concerning capital integration. It is expected that the loss of management rights negatively affects this decision, while positive synergy effects (expectations of profits) will facilitate capital integration.

Several variables, recognized in the literature as important characteristics of business entities, are included as well. The size of a firm (Size) is measured with a natural logarithm of the number of employees. Market competition requires specific skills, knowledge and resources which are costly and difficult to obtain 
for small firms. For this reason, as noted by the resource-based view, small firms will view capital integration more favorably. Along the same lines, the transaction cost approach notes that the propensity of small firms towards capital integration will be larger due to the intention to reduce the risk of failure and to avoid a hold-up problem. A natural logarithm of firm's age (Age) enters the model as a proxy for experience. On the one hand, the experience provides knowledge on values, routines and the tradition of a business environment. On the other hand, experience can be related to the knowledge about buyer preferences, distribution network, business culture, and institutional framework. All these factors ease independent market activities of business entities. For the above mentioned reasons, younger firms can be more inclined toward capital integration. A negative sign is expected on both variables.

The categorical variable is included as a control for firms with at least 25 percent of foreign ownership (Own). Evidence from a number of Central and Southeast European countries over the past two decades points to a positive effect of foreign ownership on the restructuring and productivity of business entities due to knowledge and skill transfer and easier access to finance, inputs, and improvements in innovation potential. For these reasons, foreign-owned firms can view the association with other domestic firms less favorably. However, capital integration can be favored by some firms due to the opportunities for expansion on the domestic market and access to local distribution channels. Hence, there is no expectation on the sign of this variable. Table 2 provides a definition of a group of variables measuring the above described concepts. 
Table 2: Description of Variables - First Part

\begin{tabular}{|c|c|c|}
\hline Variable name & Description & Expected sign \\
\hline $\begin{array}{l}\text { Capital integration } \\
\text { propensity (capint) }\end{array}$ & $\begin{array}{l}1-\text { Unlikely } \\
2 \text { - Likely } \\
3 \text { - Very likely }\end{array}$ & - \\
\hline \multicolumn{3}{|l|}{ Independent variables } \\
\hline $\begin{array}{l}\text { Firm performance } \\
\text { (Performance) }\end{array}$ & $\begin{array}{l}\text { Three years average return on assets }(R O A) \text { of a firm } i \text { / } \\
\text { Three years average return on assets of a firm } i \text { 's industry }\end{array}$ & - \\
\hline $\begin{array}{l}\text { Subjective and } \\
\text { objective value } \\
\text { assessment (Value) }\end{array}$ & $\begin{array}{l}\text { Categorical variable ( } 1 \text { if the subjective assessment of } \\
\text { the firm's profitability in a three-year period prior to the } \\
\text { survey is lower than the objective one) }\end{array}$ & + \\
\hline $\begin{array}{l}\text { Importance of loss of } \\
\text { management control } \\
\text { (Control) }\end{array}$ & $\begin{array}{l}\text { Categorical variable ( } 1 \text { if the potential loss of } \\
\text { management control is considered important for the } \\
\text { decision on capital integration) }\end{array}$ & - \\
\hline $\begin{array}{l}\text { Long-run profit } \\
\text { expectations (Lrprof) }\end{array}$ & $\begin{array}{l}\text { Categorical variable ( } 1 \text { if the potential of long-run profits } \\
\text { is considered important for the decision on capital } \\
\text { integration) }\end{array}$ & + \\
\hline $\begin{array}{l}\text { Short-run profit } \\
\text { expectations (Srprof) }\end{array}$ & $\begin{array}{l}\text { Categorical variable ( } 1 \text { if the potential of short- run } \\
\text { profits is considered important for the decision on } \\
\text { capital integration) }\end{array}$ & + \\
\hline Firm size (Size) & Natural logarithm of the number of employees & - \\
\hline Firm age $(A g e)$ & Natural logarithm of the firm's age & - \\
\hline Firm ownership (Own) & Categorical variable ( 1 if the firm is foreign-owned) & NA \\
\hline
\end{tabular}

Source: Authors' calculations.

The model also includes several categorical variables recognized in the literature as characteristics of the strategic alliance, namely the size of the alliance (Size) taking the value of 1 if the alliance has more than five members; the share of managers involved in alliance activities (Mngown), taking the value of 1 if more than 60 percent of managers participate in alliance activities; the percentage of alliance ownership (Alown) which takes the value of 1 if a firm owns above 50 percent of the alliance; and the perception of firm autonomy within the alliance (Authon) which takes the value of 1 if a business entity has significant autonomy or can independently make decisions within the alliance with regard to capital investment, sales, costs and pricing, quality, design or promotion. A greater level of trust and thus a higher propensity towards capital integration is expected among firms in smaller alliances and a negative sign is expected on this variable. Furthermore, a higher involvement of managers in the activities of the alliance and a larger share of ownership enable a better control over alliance activities, 
while a wider autonomy in decision-making reduces fears over loss of control. It can, therefore, be expected that business entities with a larger share of ownership, a higher share of management and a wider autonomy within strategic alliances have a higher propensity towards capital integration.

The propensity towards capital integration is related to the experience in cooperation with other members of the strategic alliance. The model includes three variables constructed on the basis of the respondents' opinions on the importance of previous cooperation among strategic alliance members for trust building (Trust), knowledge and skill transfer (Transfer) and decision-making within the alliance (Decision), which take the value of 1 if firms consider previous cooperation with strategic alliance members important for any of the above outlined processes. It is expected that business entities who share a history of cooperation have a lower fear of opportunistic behavior of partners and will therefore have a greater propensity towards capital integration. Hence, a positive sign is expected on all three variables. Table 3 provides a description of variables outlined in the two paragraphs mentioned above.

Table 3: Description of Variables - Second Part

\begin{tabular}{|c|c|c|}
\hline Variable name & Description & Expected sign \\
\hline Alliance size (Alsize) & $\begin{array}{l}\text { Categorical variable ( } 1 \text { if the alliance has more than five } \\
\text { members) }\end{array}$ & - \\
\hline $\begin{array}{l}\text { Share of ownership in } \\
\text { alliance (Alown) }\end{array}$ & $\begin{array}{l}\text { Categorical variable ( } 1 \text { if a firm owns more than } 50 \\
\text { percent of the alliance) }\end{array}$ & + \\
\hline $\begin{array}{l}\text { Percentage of managers } \\
\text { involved in alliance } \\
\text { activities (Mnginvolv) }\end{array}$ & $\begin{array}{l}\text { Categorical variable ( } 1 \text { if more than } 60 \text { percent of } \\
\text { managers participate in alliance activities) }\end{array}$ & + \\
\hline $\begin{array}{l}\text { Perception of firm } \\
\text { autonomy within the } \\
\text { alliance (Authon) }\end{array}$ & $\begin{array}{l}\text { Categorical variable ( } 1 \text { if a firm has a high degree of } \\
\text { autonomy in decision-making) }\end{array}$ & + \\
\hline Trust (Trust) & $\begin{array}{l}\text { Categorical variable ( } 1 \text { if the previous cooperation with } \\
\text { the alliance members was important for trust building) }\end{array}$ & + \\
\hline $\begin{array}{l}\text { Knowledge and skill } \\
\text { transfer (Transfer) }\end{array}$ & $\begin{array}{l}\text { Categorical variable ( } 1 \text { if the previous cooperation with } \\
\text { alliance members was important for knowledge and skill } \\
\text { transfer) }\end{array}$ & + \\
\hline $\begin{array}{l}\text { Decision-making } \\
\text { (Decision) }\end{array}$ & $\begin{array}{l}\text { Categorical variable ( } 1 \text { if the previous cooperation with } \\
\text { alliance members was important for decision-making) }\end{array}$ & + \\
\hline
\end{tabular}

Source: Authors' calculations. 
Several variables enter the model as controls for the changes in firm's performance due to participation in strategic alliance. Variable Orginno takes the value of 1 if firms consider that organizational innovations introduced through participation in alliance reduced the time required for a response to the needs of clients and suppliers, improved potential for product and process innovations, raised quality of goods and services, reduced costs and facilitated information sharing with other firms and institutions. Variable Mktinno takes the value of 1 if firms consider that marketing innovations introduced through participation in the alliance led to an increase in market share, penetration of new markets and reaching out to new customers. Business entities whose innovation activities were facilitated through participation in the alliance are expected to have a greater propensity towards capital integration than firms which did not experience such synergy effects. Thus, a positive sign is expected here as well.

The survival of firms requires meeting certain quality standards, while the social responsibility of business entities requires them to take into account environmental protection. To this end, the model includes two categorical variables for business entities which acquired internationally recognized certificates of quality (Qual) and environment protection (Env) as a consequence of participation in the strategic alliance. Possession of such certificates can signal the orientation of business entities toward long-run survival. A positive effect on propensity towards capital integration is expected. Description of these variables is provided in Table 4.

Table 4: Description of Variables - Third Part

\begin{tabular}{l|l|c}
\hline Variable name & Description & Expected sign \\
\hline $\begin{array}{l}\text { Organizational } \\
\text { innovations (Orginno) }\end{array}$ & $\begin{array}{l}\text { Categorical variable ( } 1 \text { if a firm introduced } \\
\text { organizational innovation due to strategic alliance) }\end{array}$ & + \\
$\begin{array}{l}\text { Marketing innovations } \\
\text { Mktinno) }\end{array}$ & $\begin{array}{l}\text { Categorical variable (1 if a firm introduced marketing } \\
\text { innovation due to strategic alliance) }\end{array}$ & + \\
$\begin{array}{l}\text { Quality standards } \\
\text { Qual) }\end{array}$ & $\begin{array}{l}\text { Categorical variable (1 if a firm acquired internationally } \\
\text { recognized quality certificate due to strategic alliance) }\end{array}$ & + \\
\hline $\begin{array}{l}\text { Environment } \\
\text { protection standards } \\
\text { (Env) }\end{array}$ & $\begin{array}{l}\text { Categorical variable (1 if a firm acquired internationally } \\
\text { recognized environment protection certificate due to } \\
\text { strategic alliance) }\end{array}$ & + \\
\hline
\end{tabular}

Source: Authors' calculations. 
Final sets of variables control the effect of expectations concerning the potential downsides and benefits from capital integration on prospects of such an outcome. With respect to former, three categorical variables are introduced taking the value of 1 if a business entity considers: being under threat regarding partner's opportunistic behavior (Opport), the increased costs of business (Costs), and the increased costs of coordination (Coor) as important determinants concerning the decision on capital integration. Further three categorical variables control those business entities which expect capital integration to lead towards organizational improvements (Orgben), improvements in the market (Mktben) and financial (Finben) aspects of their activities. While the former three variables are expected to negatively influence the propensity towards capital integration, the effect of the latter three is expected to be positive. Finally, categorical variables are included to control country-specific effects with Croatia being taken as the base category. Table 5 provides the description of the final set of variables.

Table 5: Description of Variables - Fourth Part

\begin{tabular}{|c|c|c|}
\hline Variable name & Description & Expected sign \\
\hline $\begin{array}{l}\text { Partner opportunism } \\
\text { (Opport) }\end{array}$ & $\begin{array}{l}\text { Categorical variable ( } 1 \text { if a firm considers potential } \\
\text { opportunistic behavior of a partner to be a barrier to } \\
\text { capital integration) }\end{array}$ & - \\
\hline $\begin{array}{l}\text { Increase in business } \\
\text { costs (Costs) }\end{array}$ & $\begin{array}{l}\text { Categorical variable ( } 1 \text { if a firm considers an increase in } \\
\text { business costs to be a barrier to capital integration) }\end{array}$ & - \\
\hline $\begin{array}{l}\text { Increase in costs of } \\
\text { coordination (Coor) }\end{array}$ & $\begin{array}{l}\text { Categorical variable ( } 1 \text { if a firm considers an increase } \\
\text { in costs of coordination to be a barrier to capital } \\
\text { integration) }\end{array}$ & - \\
\hline $\begin{array}{l}\text { Market benefits } \\
\text { (Mktben) }\end{array}$ & $\begin{array}{l}\text { Categorical variable ( } 1 \text { if a firm considers capital } \\
\text { integration to lead to an increased market share, new } \\
\text { markets penetration and improved customer satisfaction) }\end{array}$ & + \\
\hline $\begin{array}{l}\text { Financial benefits } \\
\text { (Finben) }\end{array}$ & $\begin{array}{l}\text { Categorical variable ( } 1 \text { if a firm considers capital } \\
\text { integration to lead to an increased } \mathrm{P} / \mathrm{E} \text { ratio, } R O A \text { and } \\
\text { revenue growth) }\end{array}$ & + \\
\hline $\begin{array}{l}\text { Organizational benefits } \\
\text { (Orgben) }\end{array}$ & $\begin{array}{l}\text { Categorical variable ( } 1 \text { if firm a considers capital } \\
\text { integration to lead to organizational improvements, } \\
\text { increased product range, and the expansion of capacities) }\end{array}$ & + \\
\hline Country (Ctry) & $\begin{array}{l}\text { Categorical variables (for each included country - base } \\
\text { category: Croatia) }\end{array}$ & NA \\
\hline
\end{tabular}

Source: Authors' calculations. 
The analysis is undertaken with the means of a multinomial logit econometric technique, a maximum likelihood generalized logistic regression for situations where a dependent variable takes two or more outcomes. The use of this model enables an estimation of the relative probability of choice between two or more offered alternatives. For $\mathrm{n}$ alternatives, multinomial logit estimates n-1 equations and confronts them to the base category. The underlying assumption behind estimation is that the probability of choice of one alternative over another is independent of other alternatives which are considered irrelevant in that case. Such assumption originates from the nature of logistic regression and assumption about independently distributed and homoscedastic disturbances (Greene, 2002). To control for potential heteroscedasticity, robust standard errors are used. Table 2 provides the names and descriptions of variables.

\section{Discussion of the Findings}

The first step in the estimation of econometric models is the assessment of their validity through relevant model diagnostics. One of the key assumptions of multinomial logistic models is the independence of irrelevant alternatives (IIA). This assumption implies that the inclusion or exclusion of additional categories does not affect the relative ratio of probabilities related to independent variables in other categories. A common test for IIA is the Hausman test where the null hypothesis is the independence of alternatives. Results of the Hausman test, presented in Table 6, reveal that there is insufficient evidence to reject the hypothesis on the independence of alternative specifications.

Table 6: Independence of the Irrelevant Alternatives Test

\begin{tabular}{l|c|c|c}
\hline Alternative & chi2 & Degrees of freedom & p > chi2 \\
\hline Unlikely & 30.551 & 33 & 0.590 \\
Likely & 15.670 & 33 & 0.995 \\
Very likely & 22.503 & 33 & 0.916 \\
\hline
\end{tabular}

Source: Authors' calculations. 
Further testing procedure addresses the possibility that independent variables do not significantly influence the probability of choice of a particular outcome over others. If none of the independent variables influences the probability of choice of a particular outcome over others significantly, more efficient estimation of parameters can be obtained through joining of individual outcomes (e.g., outcome: likely and very likely). Results of the Wald and LR test, presented in Table 7, reveal that none of the three possible outcomes can be combined with the remaining ones. Keeping the above mentioned in mind, it can be concluded that relevant diagnostics provide support to the model.

Table 7: Combination of the Alternatives Test

\begin{tabular}{|c|c|c|c|}
\hline Test/Alternative & chi2 & Degrees of freedom & p > chi 2 \\
\hline Wald test & \multicolumn{3}{|c|}{$\mathrm{H}_{0}$ : Alternatives can be combined } \\
\hline Unlikely and likely & 118.656 & 32 & 0.000 \\
\hline Likely and very likely & 93.890 & 32 & 0.000 \\
\hline Unlikely and very likely & 82.131 & 32 & 0.000 \\
\hline LR test & \multicolumn{3}{|c|}{$\mathrm{H}_{\mathrm{o}}$ : Alternatives can be combined } \\
\hline Unlikely and likely & 243.021 & 32 & 0.000 \\
\hline Likely and very likely & 182.614 & 32 & 0.000 \\
\hline Unlikely and very likely & 106.815 & 32 & 0.000 \\
\hline
\end{tabular}

Source: Authors' calculations.

Results obtained through the estimation are presented in form of relative risk ratios, i.e. the probability of choice of one outcome over the baseline category. Relative risk ratio is calculated as an exponent of linear coefficients obtained through the regression analysis. Such obtained figures are interpreted in a way where values below 1 suggest that unit change in independent variable reduces the probability of choice of an alternative over the base category, while values above 1 suggest the opposite. In continuation of the analysis, results are presented in terms of both linear coefficients and relative risk ratios. However, for expositional convenience, further interpretation will be undertaken with the means of relative risk ratios. 
Table 8 presents the estimation of the impact of independent variables on the choice of respondents between alternatives 1 and 2 (capital integration unlikely and capital integration likely). Results, as seen in Table 8, regarding performance indicators, subjective and objective value assessment, loss of control perception, and short- and long-run profit expectations, are all significant. Obtained findings are in line with the expectations. Better performing business entities are less inclined towards capital integration as expected. Furthermore, business entities whose subjective value assessment is lower than the objective one have a higher propensity towards capital integration. It also seems that the aversion towards loss of management control reduces the propensity towards capital integration, while the expectations of long-run profits have a positive effect.

Among the characteristics of business entities, the only significant variable is the size of the firm. The magnitude of the coefficient suggests that larger business entities are more prone to capital integration, which is not in line with the expectations. A likely explanation is that through capital integration large firms try to eliminate their competition. Based on the findings concerning the characteristics of strategic alliances, it can be concluded that business entities in alliances with a larger number of members, and those with a higher share of ownership in alliance favor capital integration more than their counterparts from alliances with fewer members and those with a smaller share of alliance ownership. While the latter finding is expected, the former is opposite to our expectations. A likely explanation is that capital integration is more favored in large alliances as it can reduce complexities in alliance activities. 
Table 8: Results of the Analysis (Base Category: Option Capital Integration "Unlikely"; Option Capital Integration "Likely")

\begin{tabular}{|c|c|c|c|}
\hline Variable & Linear coefficient & Relative risk ratio & p-value \\
\hline Performance & -0.03 & 0.97 & $0.053^{*}$ \\
\hline Value & 0.67 & 1.96 & $0.016^{* *}$ \\
\hline Control & -1.63 & 0.20 & $0.000^{* * *}$ \\
\hline Lrprof & 1.445 & 4.24 & $0.001^{* * *}$ \\
\hline Srprof & 0.39 & 1.48 & 0.460 \\
\hline Size & 0.20 & 1.22 & $0.064^{*}$ \\
\hline Age & -0.02 & 0.98 & 0.935 \\
\hline Own & 0.29 & 1.33 & 0.439 \\
\hline Alsize & 3.13 & 22.88 & $0.000^{* * *}$ \\
\hline Alown & 2.55 & 12.76 & $0.044^{* *}$ \\
\hline Mnginvolv & -0.47 & 0.62 & 0.331 \\
\hline Authon & -0.07 & 0.93 & 0.884 \\
\hline Trust & -2.20 & 0.11 & $0.000^{* * *}$ \\
\hline Transfer & -1.53 & 0.22 & $0.003^{* * *}$ \\
\hline Decision & 2.03 & 7.61 & $0.001^{* * *}$ \\
\hline Orginno & -4.41 & 0.01 & $0.013^{* *}$ \\
\hline Mktinno & -1.33 & 0.26 & 0.148 \\
\hline Qual & 3.84 & 46.35 & $0.000^{* * *}$ \\
\hline Env & 1.69 & 5.45 & 0.197 \\
\hline Opport & 1.54 & 4.68 & 0.206 \\
\hline Costs & -1.43 & 0.24 & $0.039^{* *}$ \\
\hline Coor & -1.48 & 0.23 & $0.002^{* * *}$ \\
\hline Mktben & 0.41 & 1.51 & 0.539 \\
\hline Finben & 0.48 & 1.61 & 0.536 \\
\hline Orgben & 0.71 & 2.03 & 0.687 \\
\hline $\mathrm{ctry}_{\text {_BH }} \mathrm{BH}$ & 3.99 & 54.25 & $0.077^{*}$ \\
\hline$c_{t r y} C Z$ & 3.21 & 24.72 & $0.000^{* * *}$ \\
\hline ctry_EE & 1.19 & 3.27 & 0.141 \\
\hline ctry_HU & 2.94 & 18.82 & $0.000^{* * *}$ \\
\hline$c t r y \_P L$ & 0.83 & 2.28 & 0.185 \\
\hline ctry_SI & -1.02 & 0.36 & 0.558 \\
\hline ctry_SK & 3.06 & 21.38 & $0.001^{* * *}$ \\
\hline \multicolumn{2}{|c|}{ Number of observations } & \multicolumn{2}{|c|}{736} \\
\hline
\end{tabular}

Note: ${ }^{* * *},{ }^{* *}$ and ${ }^{*}$ denote a significance at 1,5 , and $10 \%$ significance level.

Source: Authors' calculations. 
Entities which consider previous cooperation important for trust building, knowledge, and skill transfer, as well as those which introduced some kind of organizational innovation or acquired internationally recognized quality certificate due to participation in strategic alliance, have a lower probability of capital integration. However, the opposite holds for firms which consider previous cooperation with other members of alliance important for decisionmaking within the strategic alliance. Surveyed firms also consider an increase of coordination and business costs as barriers to capital integration.

Table 9 provides the results of the estimation of the impact of independent variables on the choice between unlikely and very likely capital integration. As mentioned previously, the propensity towards capital integration increases if the subjective value assessment underscores the objective one, and among those subjects who consider long-run profit expectations important for capital integration. On the other hand, potential loss of control and a better performance of a business entity reduce the propensity towards capital integration. Larger firms seem to be more prone towards capital integration while the opposite holds true for foreign-owned firms. Such findings can be interpreted in the context of gaining an easier access to business resources through channels of their foreign owners. Among alliance characteristics, business entities in alliances with a larger number of members are more likely to engage in capital integration. However, the coefficient on the variable in control of the involvement of firm's management in activities of alliance suggests that such firms have a lower probability of engaging in capital integration. Together, these findings seem to support our earlier reasoning. Firms in alliances with a larger number of firms favor capital integration as a means of reducing alliance complexities, while their management, aware of these problems, is less favorable toward further association with other firms. 
Table 9: Results of the Analysis (Base Category: Option Capital Integration "Unlikely"; Option Capital Integration "Very Likely")

\begin{tabular}{|c|c|c|c|}
\hline Variable & Linear coefficient & Relative risk ratio & p-value \\
\hline Performance & -0.03 & 0.97 & $0.046^{* *}$ \\
\hline Value & 0.83 & 2.29 & $0.006^{* * *}$ \\
\hline Control & -1.30 & 0.27 & $0.000^{* * *}$ \\
\hline Lrprof & 0.85 & 2.34 & $0.042^{* *}$ \\
\hline Srprof & 0.69 & 1.99 & 0.184 \\
\hline Size & 0.20 & 1.22 & $0.052^{*}$ \\
\hline Age & 0.13 & 1.14 & 0.515 \\
\hline Own & -2.01 & 0.13 & $0.001^{* * *}$ \\
\hline Alsize & 1.23 & 3.42 & $0.095^{*}$ \\
\hline Alown & 1.20 & 3.32 & 0.210 \\
\hline Mnginvolv & -1.37 & 0.26 & $0.003^{* * *}$ \\
\hline Authon & -0.36 & 0.70 & 0.474 \\
\hline Trust & -0.38 & 0.68 & 0.538 \\
\hline Transfer & -0.63 & 0.53 & 0.158 \\
\hline Decision & 0.09 & 1.10 & 0.878 \\
\hline Orginno & -1.00 & 0.37 & 0.562 \\
\hline Mktinno & 0.60 & 1.82 & 0.420 \\
\hline Qual & 0.82 & 2.28 & 0.214 \\
\hline Env & 2.47 & 11.83 & $0.072 *$ \\
\hline Opport & 3.79 & 44.23 & $0.001^{* * *}$ \\
\hline Costs & 1.09 & 2.97 & $0.086^{*}$ \\
\hline Coor & -1.51 & 0.22 & $0.001^{* * *}$ \\
\hline Mktben & -0.26 & 0.77 & 0.672 \\
\hline Finben & -1.61 & 0.19 & $0.015^{* *}$ \\
\hline Orgben & -2.40 & 0.09 & 0.130 \\
\hline $\mathrm{ctry}_{2} \mathrm{BH}$ & -1.32 & 0.27 & 0.510 \\
\hline$c_{t r y} C Z$ & 1.81 & 6.11 & $0.001^{* * *}$ \\
\hline ctry_EE & 0.23 & 1.26 & 0.752 \\
\hline ctry_HU & 1.90 & 6.66 & $0.005^{* * *}$ \\
\hline ctry_PL & -0.32 & 0.72 & 0.600 \\
\hline ctry_SI & -1.20 & 0.30 & 0.380 \\
\hline ctry_SK & -0.03 & 0.97 & 0.966 \\
\hline \multicolumn{2}{|c|}{ Number of observations } & \multicolumn{2}{|c|}{736} \\
\hline
\end{tabular}

Note: ${ }^{* * *},{ }^{* *}$ and ${ }^{*}$ denote a significance at 1,5 , and $10 \%$ significance level.

Source: Authors' calculations. 
The acquisition of certificate on environment protection through strategic alliance increases the chances of capital integration. Similar findings hold true for firms which consider potential opportunism and increased costs of business as possible effects of capital integration. On the one hand, this signals that firms try to protect themselves from potential opportunism of partners through capital integration. On the other hand, it seems that for business entities, who consider capital integration very likely, the rise of business costs is seen as a necessary part of adjustment to the new business conditions. Finally, the rise of costs of coordination reduces the chances of capital integration.

\section{Conclusions}

Improvement of market position requires continuous upgrading of competitive advantages. For numerous business entities the lack of their own human, capital, technological, financial and other resources presents an important obstacle to the achievement of this objective. For such business entities, supplement of one's own weaknesses through cooperation and integration with other business entities remains a precondition for survival and expansion. The benefits of synergy include a better cost and organizational efficiency, stronger negotiating power with suppliers and distributors, barriers to entry and greater customer satisfaction. However, integration of resources brings along the loss of autonomy in decision-making, complicates the relationships within the alliance and comes together with the risk of opportunistic partner behavior. From the point of view of a business entity, the decision on capital integration requires the analysis of a trade-off between previously mentioned benefits and the negative effects of synergy.

Business entities make a choice between different forms of association depending on the specificity of the desired objectives. Short-run objectives, which are not characterized by specific resources, can be achieved through strategic alliance. However, the achievement of long-run objectives requires from business entities 
a stronger form of institutional integration, such as capital integration. Feasibility of the latter process depends on the readiness of business entities to make compromise and undergo structural changes. The decision on capital integration is also determined by subjective factors, such as the perception of the firm's value and the attitude towards the loss of managerial control. Everything said suggests that the decision on capital integration is a complex process which depends on a number of objective and subjective factors.

The aim of this paper was to explore which factors and forces determine the propensity of business entities, strategic alliance members, in the retail sectors of several Central and Southeast European countries towards capital integration. To this end, particular attention was given to the effects of firm performance, value assessment, loss of autonomy and managerial control, as well as profit expectations on capital integration. The past two decades in Central and Southeast European countries were characterized by processes of transition and restructuring. The loss of traditional markets, the dissolvement of existing distributional networks and the pressure of foreign-frequently more competitive rivals — on the domestic market, as well as changes in customer preferences, have made the adjustment to new-market environment a precondition for survival. This was particularly emphasized in case of business entities whose activities are constrained by a lack of previously mentioned resources. Integration of these resources paves the way to their survival and improved competitiveness.

The results based on the questionnaire developed for the purpose of this paper reveal a low propensity of business entities towards capital integration. Better performance, fear of the loss of managerial control and a fear of opportunistic partner behavior, as well as a high subjective assessment of the firm's value, are among the key reasons behind such development. It seems therefore that firms view capital integration primarily as means of survival in a competitive environment. The chances of capital integration are also determined in accordance with the firm's size, degree of trust among partners, costs of coordination, and business activities. 
Overall, the obtained findings suggest that business entities engage in integration with the aim of reaching hidden knowledge and skills, accessing distribution and supply channels, and developing new products and services. Integration is also driven with the aim of risk diversification and possible better market positioning, achieving economies of scale, and improving organization and marketing. Its strongest barrier is the opportunistic behavior of partners and limited managerial control. To this end, the importance of previous cooperation as a factor which facilitates trust building, knowledge and skill transfer, and reaching compromise in the decision-making process, is emphasized. How can these findings be understood? Together, they point to obvious market failures in the analyzed countries. Such failures prevent the realization of transaction through market mechanism and force firms to seek various forms of association as channels for overcoming these obstacles. 


\section{Literature}

Anand, Bharat N. and Tarun Khanna, 2000, "Do Firms Learn to Create Value? The Case of Alliances", Strategic Management Journal, 21(3), pp. 295-315. https:// doi.org/10.1002/(SICI)1097-0266(200003)21:3<295::AID-SMJ91>3.0.CO;2-O

Bain, Joe S., 1968, Industrial Organization, New York, NY: Wiley.

Barkema, Harry G. and Mario Schijven, 2008, "How Do Firms Learn to Make Acquisitions? A Review of Past Research and an Agenda for the Future", Journal of Management, 34(3), pp. 594-634. https://doi.org/10.1177/0149206308316968

Barros, Pedro Pita, Duarte Brito and Diogo de Lucena, 2006, "Mergers in the Food Retail Sector: An Empirical Investigation", European Economic Review, 50(2), pp. 447-468. https://doi.org/10.1016/j.euroecorev.2004.09.012

Boone, Audra L. and Vladimir I. Ivanov, 2012, "Bankruptcy Spillover Effects on Strategic Alliance Partners", Journal of Financial Economics, 103, pp. 551-569. https://doi.org/10.1016/j.jfineco.2011.10.003

Chang, Shao-Chi and Ming-Tse Tsai, 2013, "The Effect of Prior Alliance Experience on Acquisition Performance", Applied Economics, 45(6), pp. 765-773. https://doi.org/10.1080/00036846.2011.613767

Chatterjee, Patrali, 2004, "Interfirm Alliances in Online Retailing", Journal of Business Research, 57(7), pp. 714-723. https://doi.org/10.1016/S01482963(02)00362-4

Clarke-Hill, Collin M., Terry M. Robinson and Jayne Bailey, 1988, "Skills and Competence Transfers in European Retail Alliances: A Comparison Between Alliances and Joint Ventures", European Business Review, 98(6), pp. 300-310. https://doi.org/10.1108/09555349810241572

Coase, Ronald H., 1937, “The Nature of the Firm”, Economica, 4(16), pp. 386405. https://doi.org/10.1111/j.1468-0335.1937.tb00002.x 
Cyert, Richard M. and James G. March, 1963, A Behavioral Theory of the Firm, Englewood Cliffs, NJ: Prentice Hall.

Davis, Gerald F. and J. Adam Cobb, 2010, "Resource Dependence Theory: Past and Future", Research in the Sociology of Organization, 28(1), pp. 21-42. https:// doi.org/10.1108/S0733-558X(2010)0000028006

Dyer, Jeffrey H., Prashant Kale and Harbir Singh, 2003, "When to Ally and When to Acquire", Harvard Business Review, 82(7-8), pp. 108-115.

Fang, Yiwei, Dawei Jin, Xian Sun and Haizhi Wang, 2015, "New Evidence on Alliance Experience and Acquisition Performance: Short-Run Pain, Long-Run Gain?", Studies in Economics and Finance, 32(1), pp. 53-73. https:// doi.org/10.1108/SEF-07-2014-0130

Fich, Eliezer M., Tu Nguyen and Micah S. Officer, 2016, "Large Wealth Creation in Mergers and Acquisitions", paper presented at the "AFA 2013 San Diego Meetings", Social Science Research Network (SSRN). http://dx.doi.org/10.2139/ ssrn.2020507

Geyskens, Inge, Jan-Benedict E. M. Steenkamp and Nirmalya Kumar, 2006, "Make, Buy or Ally: A Transaction Cost Theory Meta Analysis", Academy of Management Journal, 49(3), pp. 519-543. https://doi.org/10.5465/ AMJ.2006.21794670

Greene, William H., 2002, Econometric Analysis, 5th edition, Englewood Cliffs, NJ: Prentice Hall.

Hakansson, Hakan and Ivan Snehota, 1995, Developing Relationships in Business Networks, London: Routledge.

Haworth, Matthew, Sian Owen and Alfred Yawson, 2012, "A Comparative Analysis of Strategic Alliances and Acquisition Activity: A Test of the Substitution Hypothesis", paper presented at the conference "European Financial Management Association Conference” organized by EFMA, Barcelona, June 27-30. 
Hendrikse, George, 2003, Economics and Management of Organizations, Berkshire: McGraw Hill.

Hillman, Amy J., Michael C. Withers and Brian J. Collins, 2009, "Resource Dependence Theory: A Review", Journal of Management, 35(6), pp. 1404-1427. https://doi.org/10.1177/0149206309343469

Hoffman, Werner H. and Wulf Schaper-Rinkel, 2001, "Acquire or Ally? - A Strategy Framework for Deciding Between Acquisition and Cooperation", Management International Review, 41(2), pp. 131-159.

Kayo, Eduardo Kazuo, Herbert Kimura, Mauricio Rea Patrocinio and Luis Elesbao de Oliviera Neto, 2010, “Acquisitions, Joint Ventures or Arm’s Length Alliances? Analyzing the Determinants of the Choice of Growth Strategy in Brazil from 1996 through 2007", Brazilian Administration Review, 7(4), pp. 397-412. https://doi.org/10.1590/S1807-76922010000400006

Li, Kai and Nagpurnanand Prabhala, 2007, "Self-Selection Models in Corporate Finance" in B. Espen Eckbo, ed., Handbook of Corporate Finance: Empirical Corporate Finance, Volume 1, pp. 37-86, Hanover, NH: Tuck School of Business, Dartmouth College. http://dx.doi.org/10.1016/B978-0-444-53265-7.50016-0

Madhok, Anoop and Stephen B. Tallman, 1998, "Resources, Transactions and Rents: Managing Value through Interfirm Collaborative Relationships", Organization Science, 9(3), pp. 326-339. https://doi.org/10.1287/orsc.9.3.326

Nelson, Richard R. and Sidney G. Winter, 1982, An Evolutionary Theory of Economic Change, Cambridge, MA: Belknap Press.

North, Douglass C., 1990, Institutions, Institutional Change and Economic Performance, Cambridge: Cambridge University Press. https://doi.org/10.1017/ CBO9780511808678

Pfeffer, Jeffrey and Gerald R. Salancik, 2003, The External Control of Organizations: A Resource Dependence Perspective, Stanford, CA: Stanford University Press. 
Saxton, Todd, 1997, "The Effects of Partner and Relationship Characteristics on Alliance Outcomes", Academy of Management Journal, 40(2), pp. 443-461. https://doi.org/10.2307/256890

Trapido, Denis, 2007, "Competitive Embeddedness and the Emergence of Interfirm Cooperation”, Social Forces, 86(1), pp. 165-191. https:/doi.org/10.1353/ sof. 2007.0110

Villalonga, Belen and Anita M. McGahan, 2005, "The Choice among Acquisitions, Alliances, and Divestitures", Strategic Management Journal, 26(13), pp. 1183-1208. https://doi.org/10.1002/smj.493

Wang Linhua and Edward J. Zajac, 2007, "Alliance or Acquisition? A Dyadic Perspective on Interfirm Resource Combinations", Strategic Management Journal, 28(13), p. 1291-1317. https://doi.org/10.1002/smj.638

Wegberg, Marc, 1995, "Cooperation Between Research Companies and Manufacturing Firms: The Choice between Market Contract, Vertical Merger, and an R\&D-Alliance", Research Memorandum 006, Maastricht: Maastricht University, Maastricht Research School of Economics of Technology and Organization (METEOR).

Williamson, Oliver, 1985, The Economic Institutions of Capitalism: Firms, Markets, Relational Contracting, New York, NY: Free Press.

Yin, Xiaoli and Mark Shanley, 2008, "Industry Determinants of the 'Merger Versus Alliance' Decision", Academy of Management Review, 33, pp. 473-491. https://doi.org/10.5465/AMR.2008.31193515

Yu, Han and Zhaozhao He, 2014, "Cohabitation Before Marriage? An Examination of Pre-Acquisition Alliance Partnerships and Merger Outcomes", Social Science Research Network (SSRN). http://dx.doi.org/10.2139/ssrn.2435527 